\title{
Study on Winter Indoor Thermal Environment of Temporary Shelters Built in Nepal After Massive Earthquake 2015
}

\author{
Rita Thapa ${ }^{1, *}$, Hom Bahadur Rijal ${ }^{1}$, Masanori Shukuya ${ }^{1}$, Hikaru Imagawa ${ }^{1}$ \\ ${ }^{1}$ Graduate School of Environmental and Information Studies, Tokyo City University, Yokohama, Japan \\ Corresponding Email: thapareeta19@gmail.com
}

\begin{abstract}
:
Natural disasters and wars are main reasons that force people to leave their homes and consequently require urgent needs including temporary shelters. After massive earthquake 2015, thousands of Nepalese who lost their home were doomed to live in temporary shelters, mostly self-built by using zinc/tarpaulin sheets which can hardly provide sufficient thermal comfort. We need to analyze the thermal characteristics of the temporary shelters for creating a better environment for their own sake. Thus, this study tries to evaluate the winter indoor thermal environment of different types of local materials used for insulation in these investigated shelters. The indoor and outdoor thermal environment was measured by digital data loggers at the 10-minute intervals for winter in thirteen different shaped shelters in main three earthquake affected districts: Gorkha, Sindhupalchowk and Lalitpur. The mean indoor and mean outdoor air temperatures were found $12.3^{\circ} \mathrm{C}$ and $10.1^{\circ} \mathrm{C}$. The total heat loss coefficient estimated in thirteen shelters ranges from 74.8 to $325.9 \mathrm{~W} / \mathrm{K}$ and their specific values with respect to the ranges from 8.1 to $20.4 \mathrm{~W} /\left(\mathrm{m}^{2} . \mathrm{K}\right)$. These values are very large in comparison to those in ordinary houses; this is the major reason of low indoor air temperature especially during nighttime. This suggests that some insulating materials need to be added or replaced with the materials used for the improvement for better indoor thermal environment.
\end{abstract}

Keywords: Nepal-Earthquake, Temporary Shelters, Indoor Thermal Environment, Thermal Insulation, Thermal Adjustment

\section{Introduction}

Nepal had experienced many devastating earthquake and history shows that large earthquake triggered in an average of 70-80 years. Two major earthquakes struck Nepal in $25^{\text {th }}$ April with 7.8 magnitudes and $12^{\text {th }}$ May with 7.3 magnitudes, affected around 6 million people, across many districts of the country [1]. After this massive earthquake, people try to build makeshift shelters themselves by using their traditional method and available local materials i.e. zinc sheet, tarpaulin or plastic sheet. Most of the people were not aware of how the indoor environment could be improved, in spite of the fact that they are using various materials used as insulations to mitigate that harsh environment. However, these thermally very conductive materials, which could not protect from unwanted heat gains and losses from winter.

It is important to ensure that shelters provided protect people against adverse seasonal environmental conditions and help reduce social problems in the disaster areas. The government should process to evaluate and have plans for the types of temporary shelters that would be most suitable for different climatic conditions and also situations considering the lifestyles of populations based on their cultural, ethnic groups and so on. It is preferred that temporary shelters are government approved with high quality resistance, light weight, easy assembly, installation, quick to construct, using recycle materials, low embodied energy, suitable suit design, thermally comfortable and good insulations for the people.

In 2001 Japan earthquake, the Japanese government provided temporary shelters where all the basic facilities were available [2]. But in Indian Gujarat earthquake 2001, the state government provided tarpaulin sheet only [3]. Thus, there are seeming significant differences in social and economic levels between Japan and India. The Nepalese government had announced for initial relief released NRs. 15,000 (USD 150) in cash to buy corrugated zinc sheets and other materials to build temporary shelters [4]. After the disaster, through the humanitarian community and other NGOs were delivering urgent supplies to the worst affected areas and the most vulnerable victims, including distribution of shelter materials and emergency non-food relief items but it was not sufficient and away to reach the victims in remote areas. After disasters and depending on how much it is severe of time, temporary housing may be required for a certain period from several months to 
several years. In the case of developing country like Nepal, the shelters were built for temporary living but they have been used for long-term. The people face extreme cold in winter and adverse effects on their health are immense. The desirable temporary housing system should offer flexible solution that allows the use of local materials, to be handed by local people. For examples, the uses of local materials and constructions techniques allow the housing solutions quickly and reduce the economically [5].

Several studies have been carried out with respect to indoor air quality and thermal comfort in temporary houses occupied after the great east Japan earthquake [6]. Some researches focused on the design and construction in the post-disaster temporary housing during the emergency phase $[7,8,9]$ and some researchers have focused on simulation to improve of temporary shelters $[10,11,12]$. In the context of Nepal, some researches have been done to relate the indoor thermal environment [13] and acceptable indoor air temperature in temporary shelters [14].

The number of natural disasters has drastically increased in the last decades, having considerable impacts on the built environment. Indoor environment and living condition under different temporary shelters are an important area of concern and need an urgent attention in the context of unpleasant disasters. The provision of temporary housing has a vital role in disasters situations and consequence the demand of temporary shelters will continue to exist. Temporary shelters provide the people only with the indoor environmental conditions to be temporally but we need to find what kinds of characteristics should be taken into consideration for the people to have a better environment for their own sake. It might be useful to make some required improvements in the indoor thermal environment of temporary shelters. Thus, this research evaluates the indoor thermal environment of those temporary shelters built in Nepal on the basis of different materials used as insulations.

\section{Methodology}

\subsection{Research area}

The field measurement on indoor thermal environment and performance of the temporary shelters has been conducted in the epicenter of the first tremor of Gorkha, the most devastated and the epicenter of the second large tremor and small aftershocks of Sindhupalchowk and Lalitpur districts (Figure 1). Nepal has a variety of altitudes from 60 to $8848 \mathrm{~m}$ where the three investigated districts are range in altitude between 1100 to $1400 \mathrm{~m}$.

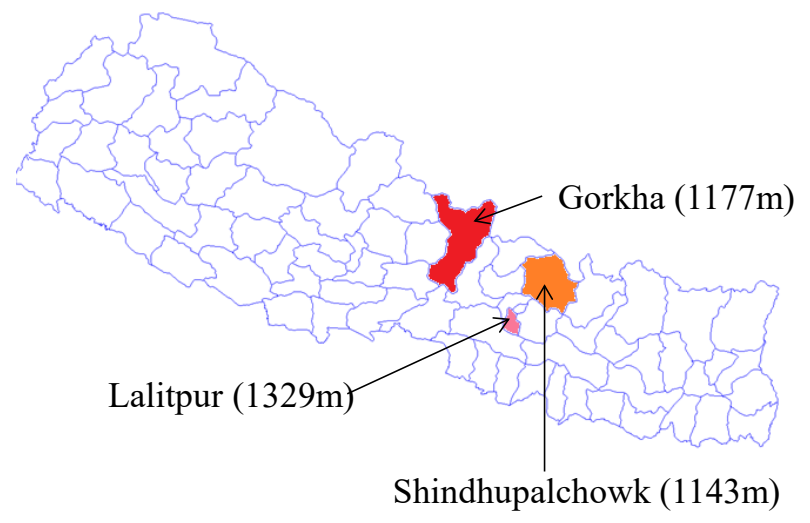

Figure 1: Map of Nepal with investigated districts (The numbers in the bracket denote the altitude)

\section{$2.2 \quad$ Climate}
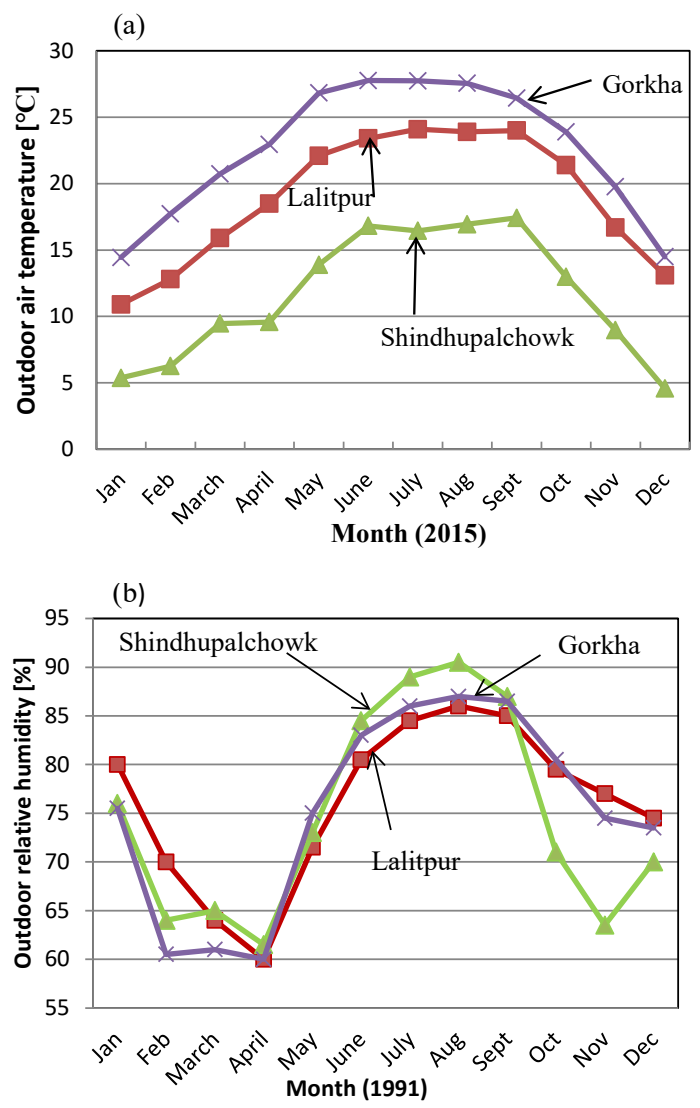

Figure 2: The climate of investigated areas: (a) Monthly mean outdoor air temperature (2015) and (b) Monthly mean outdoor relative humidity (1991)

Nepal has three climate regions: subtropical; temperate; and cold. The investigated three districts are within the temperate climate. Winter is started from November to February. Figure 2 (a) illustrates the general information of monthly mean outdoor air temperature obtained from 
the nearest meteorological stations of those investigated districts [15].

The names of weather stations are: Lalitpur (Khumaltar), Sindhupalchowk (Outdoor air temperature taken from Sarmathang and relative humidity taken from Sangachok), and Gorkha (Gorkha).

Throughout the year, the outdoor air temperature is the highest in Gorkha, the middle in Lalitpur and then the lowest in Sindhupalchowk. In all three districts, the differences in outdoor air temperature between the highest and the lowest are identical by $12-13^{\circ} \mathrm{C}$. Figure 2 (b) illustrates that throughout the yearly outdoor relative humidity fluctuate from one season to another season [16]. The relative humidity is high from June to August. The reason might be rainy season on those respective months.

\subsection{Investigated shelters}

The investigated temporary shelters: S1 to S7, S11 to S13 and S14 to S16 were located in Lalitpur, Sindhupalchowk and Gorkha districts, respectively. Among these shelters, S1, S2, S4, S5, S6 and S13 were rectangular-shaped, S3, S11, S12, S15 and S16 were dome-shaped, and S14 was triangular shaped.

We compared those investigated shelters having different structures, size and different materials used as insulation. The plan and sectional views of three different types of temporary shelters were given in our previous paper [14].

People used local and available materials for insulation, such as plastics/tarpaulins, black/white foam, mud plaster and so on under or over the zinc sheet (Table 1), although these thermal insulating characteristics are not

Table 1: Description of each shelter

\begin{tabular}{|c|c|c|c|c|c|c|c|c|}
\hline S.C. & $\mathrm{N}$ & $\begin{array}{l}\text { U-value-four } \\
\text { walls }\left[\mathrm{W} / \mathrm{m}^{2} . \mathrm{K}\right]\end{array}$ & $\begin{array}{l}\text { U-value- roof } \\
{\left[\mathrm{W} / \mathrm{m}^{2} . \mathrm{K}\right]}\end{array}$ & $\begin{array}{l}\text { Floor area } \\
{\left[\mathrm{m}^{2}\right]}\end{array}$ & Roof insulations & Wall & Window/Shading & Floor \\
\hline S1 & 4 & 5.6 & 1.2 & 17.5 & $\begin{array}{l}\text { Zinc, outdoor straw, } \\
\text { indoor thick clothes } \\
\text { and black foam }\end{array}$ & Zinc Sheet & $\begin{array}{l}3 \text { openable iron/ } \\
\text { Thick curtain }\end{array}$ & $\begin{array}{l}\text { Brick, mud plaster } \\
\text { and carpet }\end{array}$ \\
\hline S2 & 3 & 5.6 & 1.6 & 6.3 & $\begin{array}{l}\text { Zinc, outdoor straw, } \\
\text { indoor thin clothes } \\
\text { and paper cartoon }\end{array}$ & Zinc Sheet & None & $\begin{array}{l}\text { Brick, mud plaster } \\
\text { and carpet }\end{array}$ \\
\hline S3 & 3 & 5.6 & 2.8 & 9.3 & $\begin{array}{l}\text { Zinc, indoor black } \\
\text { foam }\end{array}$ & Zinc Sheet & None & $\begin{array}{l}\text { Brick, mud plaster } \\
\text { and carpet }\end{array}$ \\
\hline S4 & 4 & 5.6 & 3.8 & 14.9 & $\begin{array}{l}\text { Zinc, indoor thick } \\
\text { clothes }\end{array}$ & Zinc Sheet & $\begin{array}{l}2 \text { openable glass/ } \\
\text { Thick curtain }\end{array}$ & $\begin{array}{l}\text { Cement plaster and } \\
\text { carpet }\end{array}$ \\
\hline S5 & 2 & 5.6 & 3.8 & 16.4 & $\begin{array}{l}\text { Zinc, indoor thick } \\
\text { clothes }\end{array}$ & Zinc Sheet & $\begin{array}{l}2 \text { openable glass/ } \\
\text { Thin curtain }\end{array}$ & $\begin{array}{l}\text { Cement plaster and } \\
\text { carpet }\end{array}$ \\
\hline S6 & 3 & 4.4 & 2.8 & 9.1 & $\begin{array}{l}\text { Zinc, outdoor straw, } \\
\text { indoor thin clothes } \\
\text { and paper cartoon }\end{array}$ & $\begin{array}{l}\text { Bamboo and } \\
\text { mud plaster }\end{array}$ & $\begin{array}{l}1 \text { openable wood/ } \\
\text { Thin curtain }\end{array}$ & $\begin{array}{l}\text { Brick, mud plaster } \\
\text { and straw mattress }\end{array}$ \\
\hline S7 & 4 & 5.6 & 4.5 & 11.7 & $\begin{array}{l}\text { Zinc, indoor black } \\
\text { foam }\end{array}$ & $\begin{array}{l}\text { Bamboo and } \\
\text { mud plaster }\end{array}$ & $\begin{array}{l}3 \text { openable iron/ } \\
\text { Thin curtain }\end{array}$ & $\begin{array}{l}\text { Brick, mud plaster } \\
\text { and straw mattress }\end{array}$ \\
\hline S11 & 3 & 4.8 & 4.5 & 10.0 & $\begin{array}{l}\text { Zinc, indoor thin } \\
\text { clothes }\end{array}$ & Plywood & $\begin{array}{l}3 \text { openable wood / } \\
\text { Thin curtain }\end{array}$ & $\begin{array}{l}\text { Brick, mud plaster } \\
\text { and carpet }\end{array}$ \\
\hline $\mathrm{S} 12$ & 5 & 4.8 & 5.6 & 10.0 & $\begin{array}{l}\text { Zinc, indoor thin } \\
\text { clothes }\end{array}$ & Zinc sheet & $\begin{array}{l}2 \text { openable wood/ } \\
\text { Thin curtain }\end{array}$ & $\begin{array}{l}\text { Brick, mud plaster } \\
\text { and straw mattress }\end{array}$ \\
\hline S13 & 4 & 5.6 & 4.5 & 11.2 & $\begin{array}{l}\text { Zinc, indoor thin } \\
\text { clothes }\end{array}$ & Zinc sheet & $\begin{array}{l}1 \text { openable wood/ } \\
\text { Thin curtain }\end{array}$ & $\begin{array}{l}\text { Brick, mud plaster } \\
\text { and mattress }\end{array}$ \\
\hline S14 & 6 & 4.4 & 4.5 & 16.7 & $\begin{array}{l}\text { Zinc, indoor thin } \\
\text { clothes }\end{array}$ & $\begin{array}{l}\text { Bamboo and } \\
\text { mud plaster }\end{array}$ & $\begin{array}{l}1 \text { openable wood/ } \\
\text { Thin curtain }\end{array}$ & $\begin{array}{l}\text { Brick, mud plaster } \\
\text { and straw mattress }\end{array}$ \\
\hline S15 & 4 & 5.6 & 4.5 & 11.1 & $\begin{array}{l}\text { Zinc, indoor black } \\
\text { foam }\end{array}$ & $\begin{array}{l}\text { Zinc sheet and } \\
\text { indoor thin } \\
\text { clothing }\end{array}$ & $\begin{array}{l}1 \text { openable wood/ } \\
\text { Thin curtain }\end{array}$ & $\begin{array}{l}\text { Brick, mud plaster } \\
\text { and carpet }\end{array}$ \\
\hline S16 & 2 & 5.6 & 4.8 & 11.1 & $\begin{array}{l}\text { Zinc, outdoor } \\
\text { tarpaulin }\end{array}$ & Zinc sheet & $\begin{array}{l}1 \text { openable wood/ } \\
\text { None }\end{array}$ & $\begin{array}{l}\text { Brick, mud plaster } \\
\text { and straw mattress }\end{array}$ \\
\hline
\end{tabular}




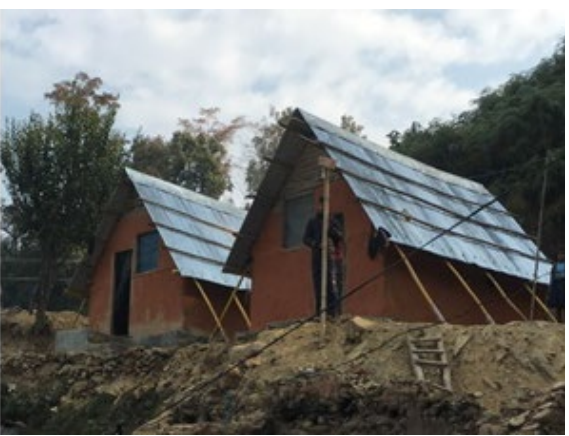

(a) Gorkha

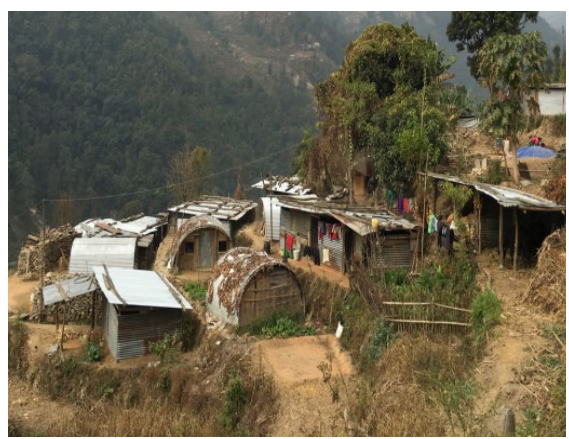

(b) Sindhupalchowk

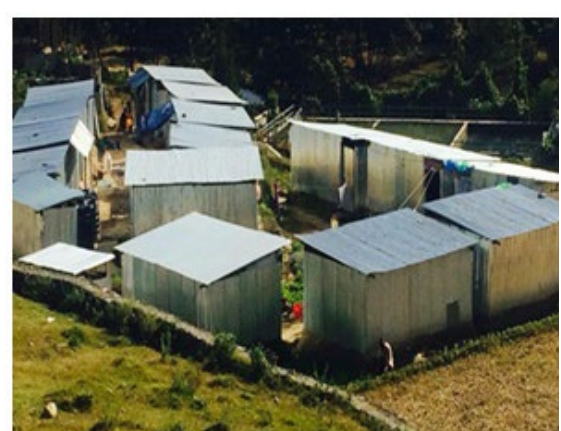

(c) Lalitpur

Figure 3: Investigated shelters in each district

good enough. These materials used are not sturdy enough to protect from harsh climatic condition.

All investigated shelters have single room for living, sleeping and kitchen purposes. There were not found any heating system applied in those investigated shelters, although sometime firewood burns during the cooking time for source of heating. The heat loss coefficient are ranging from 4.4 5.6 W/ $\left(\mathrm{m}^{2} . \mathrm{K}\right)$ for wall and 1.2 5.6 $\mathrm{W} /\left(\mathrm{m}^{2} . \mathrm{K}\right)$ for roof can be seen in Table 1 .

The total heat loss coefficients of dome-shaped shelters are lower than squared and triangular-shaped shelters. The reason might be the dome-shaped shelters' areas were found small and insulated materials also found very weak. We have categorized the good and poor insulated shelters into two groups (high and low) on the basis of total heat loss coefficient from four walls and roof, and total heat loss coefficient from four walls and roof by floor area which are explain in result and discussion section.

\subsection{Thermal measurement}

The measurement was performed in winter with thirteen temporary shelters. Table 2 shows the details of field measurement period for the investigated temporary shelters and Figure 3 shows the investigated shelters in each district. Environmental parameters such as indoor air temperature $\left(T_{i}\right)$, indoor relative humidity $\left(R H_{i}\right)$ and outdoor air temperature $\left(T_{o}\right)$ were measured by data loggers (Table 3 ) at the interval of 10 minute (Figure 4). We have measured the indoor surface temperature (ceiling, floor and walls of four directions) and indoor globe temperature $\left(T_{g}\right)$ for $\mathrm{S} 1$ only. We have measured the outdoor air temperature outside the S1 in Lalitpur and S11 in Sindhupalchowk and S14 in Gorkha.

\section{Result and discussion}

\subsection{Thermal environment}

Table 2: Details of the field measurement period

\begin{tabular}{|c|c|c|c|c|}
\hline \multirow{2}{*}{ District } & \multirow{2}{*}{$\begin{array}{l}\text { Shelter } \\
\text { code }\end{array}$} & \multicolumn{2}{|c|}{ Survey period } & \multirow{2}{*}{$\begin{array}{l}\text { Total } \\
\text { days }\end{array}$} \\
\hline & & Start date & End date & \\
\hline \multirow[t]{2}{*}{ Lalitpur } & $\mathrm{S} 1$ to $\mathrm{S} 3$ & $1 / 20 / 2016$ & $2 / 14 / 2016$ & 26 \\
\hline & $\mathrm{S} 4$ to $\mathrm{S} 7$ & $1 / 29 / 2016$ & $2 / 14 / 2016$ & 17 \\
\hline Sindhupalchowk & $\mathrm{S} 11$ to $\mathrm{S} 13$ & $1 / 19 / 2016$ & $1 / 22 / 2016$ & 4 \\
\hline Gorkha & $\mathrm{S} 14$ to $\mathrm{S} 16$ & $1 / 26 / 2016$ & $2 / 26 / 2016$ & 1 \\
\hline
\end{tabular}

Table 3: Details of the instrument used

\begin{tabular}{llll}
\hline $\begin{array}{l}\text { Name of } \\
\text { instruments }\end{array}$ & Sensors & Range & Accuracy \\
\hline TR-74Ui & $\begin{array}{l}\text { Thermistor and } \\
\text { polymer membrane }\end{array}$ & $\begin{array}{l}0-55^{\circ} \mathrm{C}, \\
10-95 \%\end{array}$ & $\begin{array}{l} \pm 0.5^{\circ} \mathrm{C}, \\
\pm 5 \% \mathrm{RH}\end{array}$ \\
\hline $\begin{array}{l}\text { Tr-52i, SIBATA, } \\
080340-75\end{array}$ & $\begin{array}{l}\text { Black painted, } 75 \\
\text { mm-diameter globe }\end{array}$ & $\begin{array}{l}-60 \text { to } \\
155^{\circ} \mathrm{C}\end{array}$ & $\pm 0.3^{\circ} \mathrm{C}$ \\
\hline
\end{tabular}
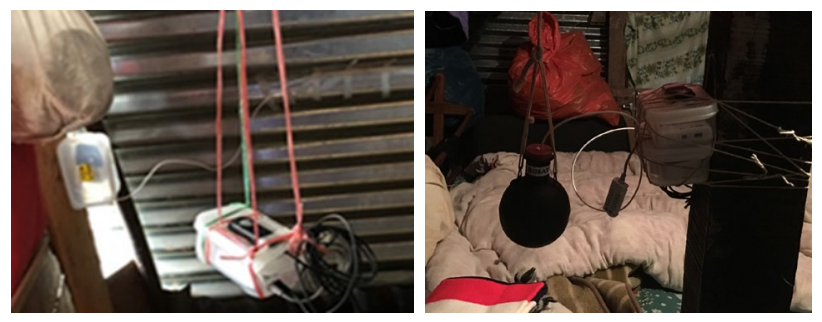

Figure 4: Installed instruments used for field measurement

\subsubsection{Indoor air temperature}

Figure 5 illustrates the distribution of indoor and outdoor air temperature of S1 to S13 in winter. The mean indoor and mean outdoor air temperatures were found $12.3^{\circ} \mathrm{C}$ and $10.1^{\circ} \mathrm{C}$. Most of the whiskers coming out of the top of the box are longer than those at the bottom; this result suggests that the fluctuation of indoor and outdoor air temperatures were large. The distribution of S3 (domeshaped) indoor air temperature during daytime is much higher than during night time. 


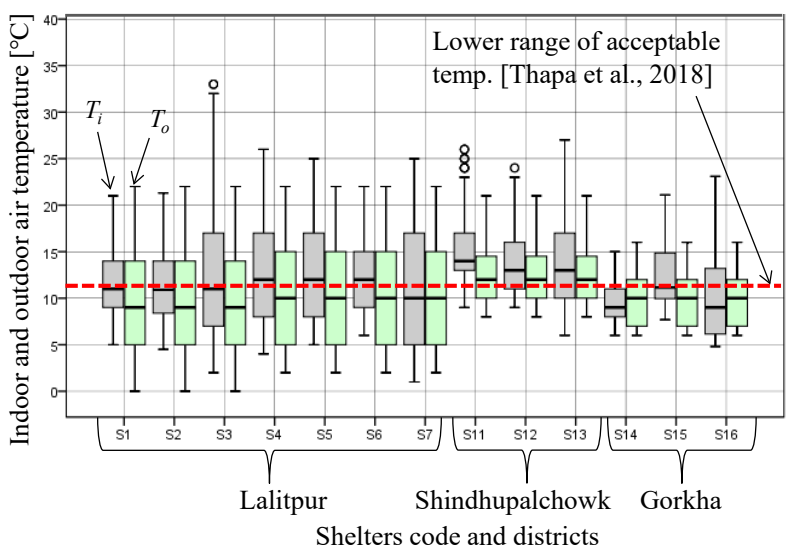

Figure 5: Distribution of indoor and outdoor air temperature in winter

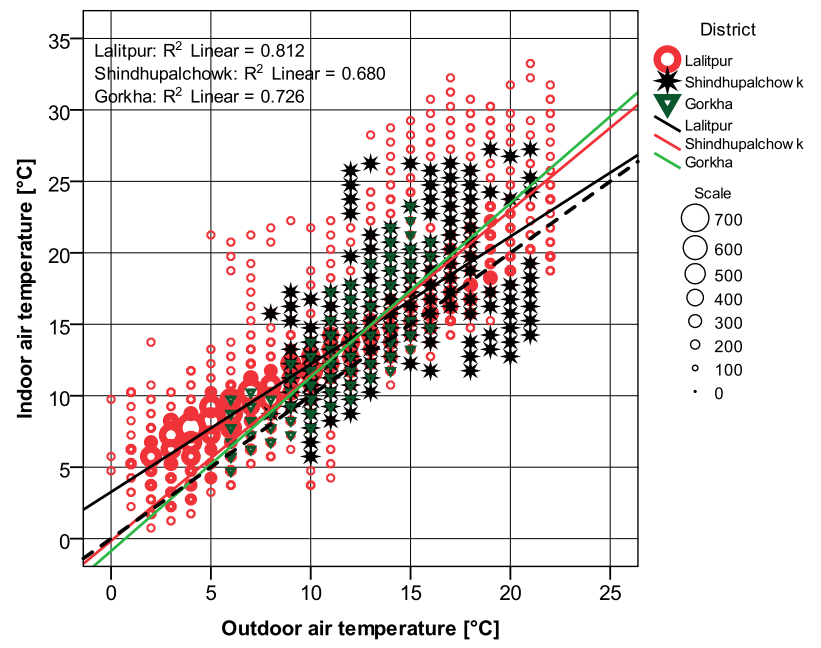

Figure 6: Relationship between indoor and outdoor air temperature of three districts in winter

In this figure, we have drawn the dashed line at $11^{\circ} \mathrm{C}$, which is the lower limit of acceptable range of indoor air temperature of respondents residing in temporary shelters [14]. As we can see, most of data are below range of the acceptable indoor air temperature. This is because the people had to use thermally very conductive thin materials which cannot protect sufficiently from outdoor environment. Thus, we need to improve the winter indoor thermal environment for thermally acceptable temporary shelters for future disaster.

\subsubsection{Relationship between indoor and outdoor air temperature}

Figure 6 illustrates the relationship between indoor and outdoor air temperature during the field measurement of 13 shelters in winter. The indoor air temperatures are correlated very well with the outdoor air temperatures. The difference in temperatures between indoor and outdoor tends to be smaller as the outdoor air temperature becomes either lower or higher; the latter is considered to be due to the large heat loss caused by a large temperature difference between indoor and outdoor temperature. These results indicate that respondents were adapted to the similar indoor air temperature as they have outdoor.

The most of the data tend to be slightly above from the diagonal line and also seems below the lower limit of acceptable indoor air temperature of $11^{\circ} \mathrm{C}$. This is due to internal heat generation and solar gain. Those living in temporary shelters tried to mitigate their problems and reduce discomfort of temporary shelters by using their own ideas and techniques as was mentioned in Table 1. These local and affordable materials used for thermal insulations are not sturdy enough but marginally useful to reduce unwanted heat losses or heat gains in winter $[17,18]$.

Here, we have obtained the following regression equation of indoor air temperature as a function of outdoor air temperature.

Lalitpur $\quad T_{i}=0.894 T_{o}+3.27\left(\begin{array}{l}N=21024, R^{2}=0.81 \\ S . E .=0.003, P<0.001\end{array}\right)$

$\begin{array}{ll}\text { Sindhu } & T_{i}=1.156 T_{o}-0.15\left(\begin{array}{c}N=1728, R^{2}=0.68, \\ \text { S.E. }=0.019, P<0.001\end{array}\right)\end{array}$

Gorkha $\quad T_{i}=1.22 T_{o}-0.87\left(\begin{array}{c}N=432, R^{2}=0.77, \\ \text { S.E. }=0.036, P<0.001\end{array}\right)$

Where, $\mathrm{N}$ : Number of samples, $\mathrm{R}_{2}$ : Coefficient of determination, S.E.: Standard error of the regression coefficient, P: Significance level of the regression coefficient.

In Lalitpur, the slope is lower than other two districts of Shindhupalchowk and Gorkha. The results showed that the indoor and outdoor air temperatures are very similar in Lalitpur district, and thus regional differences of the indoor and outdoor are quite large. The constant (y intercept), 3.27 in Lalitpur, eq. (1), is 2 to $3^{\circ} \mathrm{C}$ higher than eq. (2) and eq. (3) in Shindhupalchowk and Gorkha. These tendencies are considered to reflect the characteristics of makeshift shelters build of zinc sheets.

\subsubsection{Mean indoor and outdoor air temperature in day, night and sleeping time}

Table 4 illustrates the result of mean indoor and mean outdoor temperature of day, night and sleeping time of each shelter. The mean indoor temperature of day, night and sleeping time for S7, S13 and S16 are found to be lower than others investigated shelters in Lalitpur, Sindhupalchowk and Gorkha. The night time mean indoor air temperatures of thirteen shelters are almost 
similar to mean outdoor air temperatures. The reason is that the thermally good conductor materials used as insulations. The day time mean indoor air temperatures of all investigated shelters are ranges between 12.6 $\sim 17.4^{\circ} \mathrm{C}$ found in this study. According to the previous study [19], the daily mean indoor air temperature of traditional houses was found the range between $6.5 \sim 15.3^{\circ} \mathrm{C}$, which are quite near with this result.

In this study, we have focused the indoor sleeping time temperature. The sleeping time varied with sex, age, season and geographical region. Sleep required vary slightly from person to person, however adults need between 7-9 hours of sleep per night to function their day work best [20]. So, we have defined the sleeping hour at 21:00 5:50. During the sleeping time mean indoor air temperature are ranges between $5.4 \sim 10.4^{\circ} \mathrm{C}$ for all thirteen shelters. The sleeping time mean indoor air temperature in $\mathrm{S} 7$ is $5.4^{\circ} \mathrm{C}$ which is $4.5 \mathrm{~K}$ lower than shelter S6. The mean indoor air temperature of night time and sleeping time were found the lower limit of acceptable indoor air temperature of $11{ }^{\circ} \mathrm{C}$. The mean maximum indoor air temperature of ordinary building is 12 to $15^{\circ} \mathrm{C}$ [21] which are quite close with this result $\left(10.5 \sim 17.4^{\circ} \mathrm{C}\right)$ as can be seen in Table 4. It suggests that indoor air temperatures are very low and creates several problems related to coldness. The characteristics of those investigated shelters are found to be extremely cold. However, the people are trying to adapt these harsh indoor environments by adjusting their clothes [14].

According to Sagiroglu and Memari [22], insulation is a vital aspect to accommodate thermal resistance based on external climate. They showed that the houses without insulation materials especially in the temperature below $8^{\circ} \mathrm{C}$, cold and uncomfortable in terms of indoor temperature. Thus, it can be concluded that, insulations play vital role to accommodate the good thermal resistance based on external climate. It can be said that, the investigated shelters need to be improved for better settlement for their own sake and the possible required solutions should be proposed for future disasters.

\subsection{Thermal performance of investigated shelters}

\subsubsection{Total heat loss coefficient}

Figure 7 (a) illustrates that the total heat loss coefficient from four walls and roof of S1 to S13 ranges from 74.8 to $325.9 \mathrm{~W} / \mathrm{K}$. Figure 7 (b) illustrates that the total heat

Table 4: Mean indoor and mean outdoor air temperature in day, night and sleeping time

\begin{tabular}{|c|c|c|c|c|c|c|c|c|c|c|c|}
\hline \multirow{2}{*}{ District } & \multirow{2}{*}{ S.C. } & \multirow{2}{*}{ Variables } & \multicolumn{3}{|c|}{ Day time $(6: 00 \sim 17: 50)$} & \multicolumn{3}{|c|}{ Night time (18:00 5:50) } & \multicolumn{3}{|c|}{ Sleeping time $(21: 00 \sim 5: 50)$} \\
\hline & & & $\mathrm{N}$ & Mean & S.D & $\mathrm{N}$ & Mean & S.D & $\mathrm{N}$ & Mean & S. D \\
\hline \multirow{7}{*}{ Lalitpur } & $\mathrm{S} 1$ & \multirow{7}{*}{$\mathrm{T}_{\mathrm{i}}$} & 1872 & 12.6 & 3.9 & 1872 & 10.2 & 2.2 & 1404 & 9.5 & 1.8 \\
\hline & $\mathrm{S} 2$ & & 1872 & 12.9 & 4.3 & 1872 & 10.0 & 2.4 & 1404 & 9.1 & 1.8 \\
\hline & S3 & & 1872 & 16.9 & 8.0 & 1872 & 9.3 & 3.1 & 1404 & 8.2 & 2.6 \\
\hline & S4 & & 1224 & 15.6 & 6.4 & 1224 & 9.8 & 3.2 & 918 & 8.4 & 2.1 \\
\hline & S5 & & 1224 & 15.2 & 5.7 & 1224 & 10.3 & 2.8 & 918 & 9.0 & 1.9 \\
\hline & S6 & & 1224 & 13.5 & 4.5 & 1224 & 11.0 & 2.6 & 918 & 9.9 & 1.9 \\
\hline & S7 & & 1224 & 14.9 & 6.9 & 1224 & 6.9 & 3.4 & 918 & 5.4 & 2.3 \\
\hline \multirow[t]{2}{*}{ All Shelters } & & $\mathrm{T}_{\mathrm{o}}$ & 1872 & 12.0 & 5.7 & 1872 & 7.0 & 3.2 & 1404 & 5.7 & 2.3 \\
\hline & S11 & & 288 & 16.5 & 4.3 & 288 & 13.9 & 1.4 & 216 & 13.4 & 1.2 \\
\hline \multirow[t]{2}{*}{ Sindhupalchowk } & $\mathrm{S} 12$ & $\mathrm{~T}_{\mathrm{i}}$ & 288 & 15.3 & 4.2 & 288 & 12.3 & 2.0 & 216 & 11.4 & 1.2 \\
\hline & S13 & & 288 & 17.4 & 5.4 & 288 & 11.4 & 2.6 & 216 & 10.4 & 1.9 \\
\hline \multirow[t]{2}{*}{ All Shelters } & & $\mathrm{T}_{\mathrm{o}}$ & 288 & 14.1 & 3.4 & 288 & 11.2 & 1.5 & 216 & 10.6 & 1.0 \\
\hline & $\mathrm{S} 14$ & & 72 & 10.5 & 2.9 & 72 & 8.5 & 1.1 & 54 & 8.0 & 0.8 \\
\hline \multirow[t]{2}{*}{ Gorkha } & S15 & $\mathrm{T}_{\mathrm{i}}$ & 72 & 14.4 & 4.3 & 72 & 10.4 & 0.9 & 54 & 10.1 & 0.8 \\
\hline & S16 & & 72 & 13.9 & 5.7 & 72 & 7.5 & 1.5 & 54 & 6.9 & 1.4 \\
\hline All Shelters & & $\mathrm{T}_{\mathrm{o}}$ & 72 & 11.2 & 3.0 & 72 & 8.2 & 1.8 & 54 & 7.5 & 1.7 \\
\hline
\end{tabular}

S.C: Shelter Code, S: Shelter, N: Number of data, Ti: Indoor air temperature $\left[{ }^{\circ} \mathrm{C}\right]$, To: Outdoor air temperature $\left[{ }^{\circ} \mathrm{C}\right]$, S.D.: Standard Deviation $\left[{ }^{\circ} \mathrm{C}\right]$. 
loss coefficient from four walls and roof by per floor area of $\mathrm{S} 1$ to $\mathrm{S} 13$ ranges from 8.1 to $20.4 \mathrm{~W} /\left(\mathrm{m}^{2} . \mathrm{K}\right)$.

We have categorized those good and poor investigated shelters into two groups (high and low) on the basis of these above total heat loss coefficient. If we see the trend of particular shelters of S6 and S7, the roof U-value of $\mathrm{S} 6$ was $2.8 \mathrm{~W} /\left(\mathrm{m}^{2} . \mathrm{K}\right)$ which was about 1.5 times smaller than $\mathrm{S} 7$, as can be seen in Table 1. The total heat loss coefficient from four walls and roof of S6 was 138.2 $\mathrm{W} / \mathrm{K}$ which was about 1.5 times smaller than $\mathrm{S} 7$, found in Figure 7 (a). The total heat loss coefficient from four walls and roof by per floor area of S6 was $15.2 \mathrm{~W} /$ $\left(\mathrm{m}^{2} . \mathrm{K}\right)$ which was 1.2 times smaller than $\mathrm{S} 7$, found in Figure 7 (b).

(a)
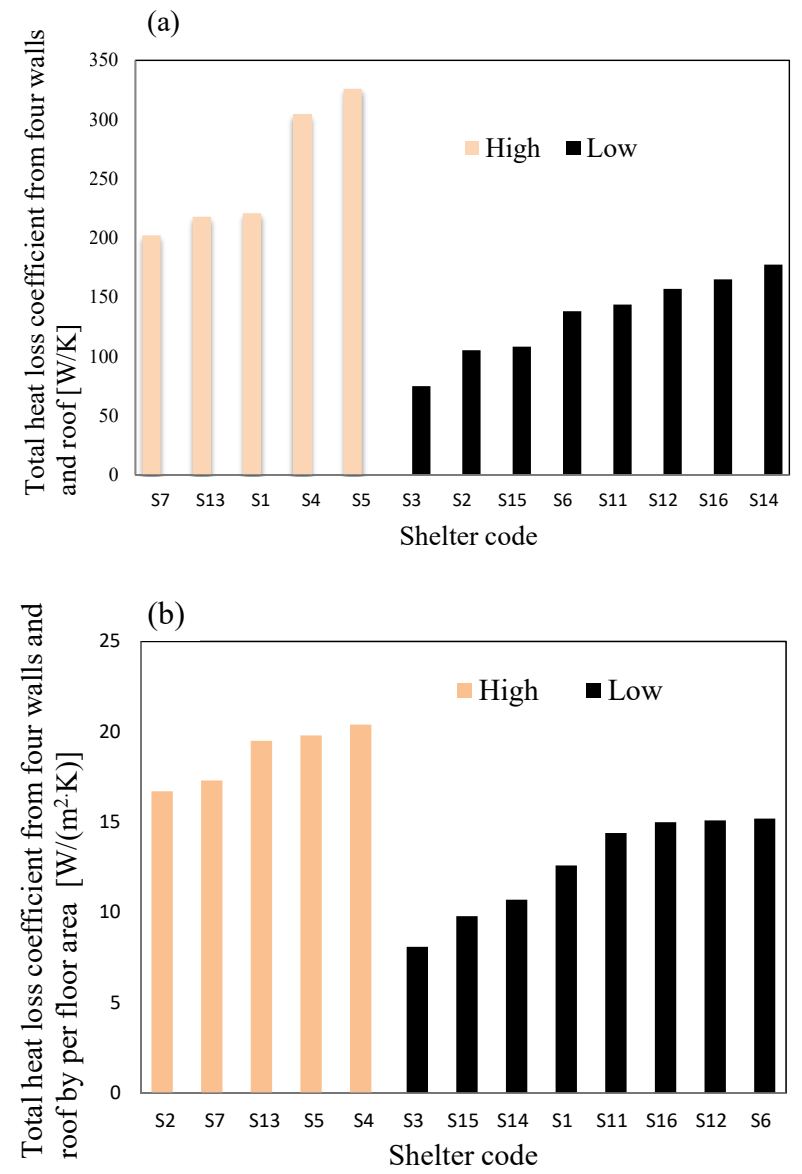

Figure 7: (a) and (b) Total heat loss coefficient of each shelter

\subsubsection{Relation between the night time indoor air temperature and total heat loss coefficient}

Figure 8 (a) and (b) illustrate the relationship between the night time indoor air temperature and total heat loss coefficient and the relationship between the night time indoor air temperature and total heat loss coefficient by per floor area. For making similarities in respective district, we have taken 16 days night time mean temperature for Lalitpur, 4 days for Sindhupalchowk and 1 day for Gorkha.

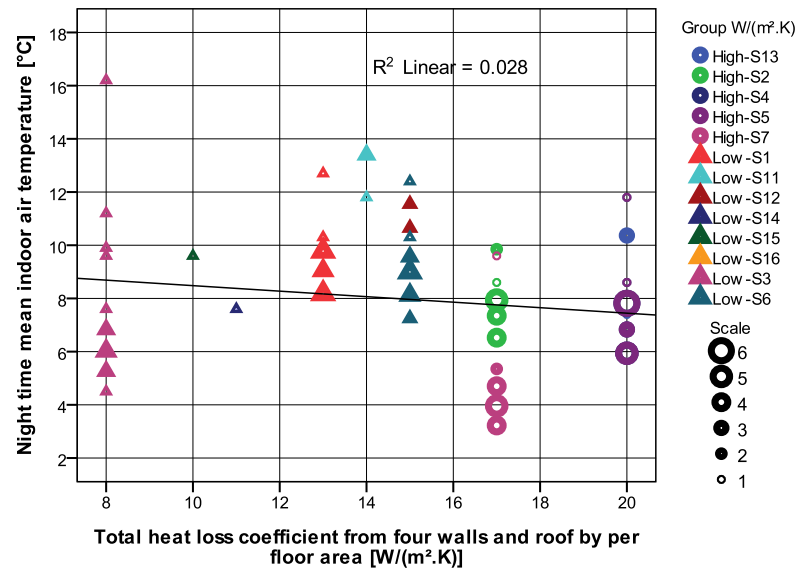

(a)

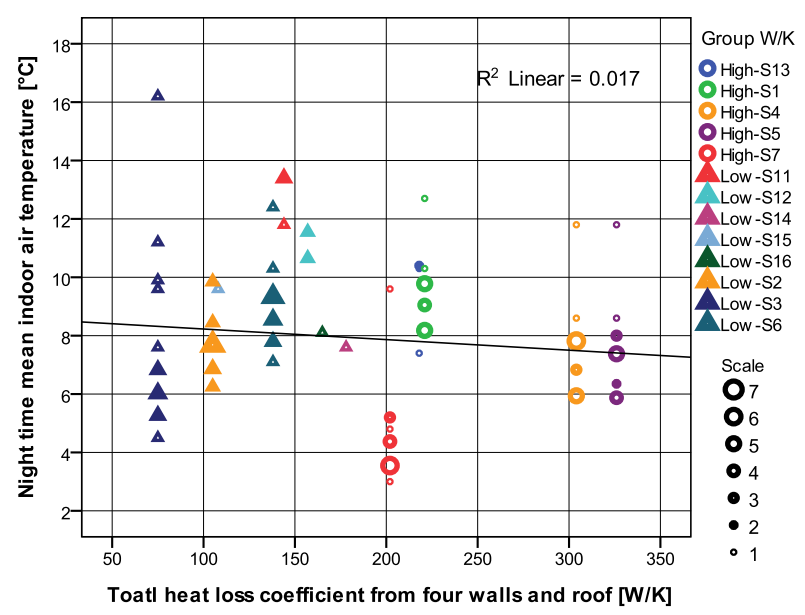

(b)

Figure 8: (a) and (b) Relationship between the air temperature and total heat loss coefficient

We have explained the night time mean indoor air temperature in terms of total heat loss coefficient from four walls and roof and heat loss coefficient. The shelters having low value of heat loss coefficient from four walls and roof and total heat loss coefficient tend to be high mean night time indoor air temperatures and vice versa having high value. These results suggest that the shelters having low value of heat loss coefficient store the inside heat and vice versa having high value.

The indoor air temperature is intrinsically low because of very low thermal insulation, but the night time mean indoor air temperature tends to decrease as the heat loss coefficient increase. Thus, night time mean indoor air temperature needs to increase up to lower range of acceptable indoor air temperature of $11^{\circ} \mathrm{C}$. For that 
purpose, we should consider that, how much insulating materials need to added or replaced with the materials used for the improvement for better indoor thermal environment of temporary shelters.

The researchers [23] developed a project and offered "The Ski Shelter", which includes assembly method, lightweight material, reused materials, and is able to maintain acceptable internal thermal comfort conditions by reducing the fuel consumption during winter season. Thus, we need to require some affordable methods for improvement which should be proposed for avoiding the harsh indoor environmental conditions of temporary shelters.

\section{Conclusions}

In this research, we measured the indoor thermal environment of temporary shelters built after massive earthquake 2015, and the following results were obtained.

1. Most of the shelters' indoor air temperatures were lower than the lower limit of acceptable temperature, $11^{\circ} \mathrm{C}$. It seems that there is more problematic and there must be quite a problem for residents' health.

2. The indoor air temperatures for all shelters are highly dependent on outdoor air temperature. The regional differences of both indoor and outdoor air temperature were found large. Thus, the people are living under almost the same temperature conditions as outdoors.

3. The mean indoor air temperatures are at $2.6 \sim 4.2^{\circ} \mathrm{C}$ higher than outdoor air temperature during the sleeping time for all investigated shelters. The sleeping time indoor air temperature is considerably lower than the ordinary houses.

4. The total heat loss coefficient from four walls and roof or by per floor area has becoming root cause of lower indoor air temperature for investigated shelters.

As a conclusion, we found that night time mean indoor air temperatures below the lower range of acceptable indoor air temperature of $11^{\circ} \mathrm{C}$.

It is required to improve the indoor environment for the sake of those people living in temporary shelters. It is also recovery for the temporary shelters to be designed for future disasters. Furthermore, the outcome of this research can contribute not only to academic research but also to the necessary policy to be made by national and international levels. Thus, we need to study further about how much insulation materials should be proposed for avoiding such harsh indoor environmental conditions of temporary shelters.

\section{Acknowledgments}

The authors are thankful to those respondents in that investigated shelters for their cooperation and Mr. Arun Khatri KC for his help in field measurement.

\section{References}

[1] Hazarika H, Bhandary NP, Kajita Y, Kasama K, Tsukahara K and Pokharel RK (2016), The 2015 Nepal Gorkha earthquake: An overview of the damage, lessons learned and challenges. Lowland Technology International: Special Issue on: Nepal Earthquake \& Disaster, 18 (2) : 129-140.

[2] Nobuo M, Kazuya Y, Seiki K, Hiromune Y, and K. So (2011), Damage from the Great East Japan Earthquake and Tsunami: A quick report. Mitigation Adapt Strategies Globe Change, (16): 803-818.

[3] Saito K, Spence RJ, Going C and Markus M (2004), Using High-Resolution Satellite Images for Post-Earthquake Building Damage Assessment: A Study Following the 26 January 2001 Gujarat Earthquake. Earthquake Spectra, 20 (1) : 145-169.

[4] Koirala J (2015), Government failure in disaster management; Evidence from Nepal earthquake. Author Orcid: Org/0000-0001-6711-828x : 1-5.

[5] Felix D, Branco JM and Feio A (2013), Temporary housing after disaster: A state of the art survey. Habitat International, (40) : 136-141.

[6] Shinohara N, Tokumura M, Kazama M, Yonemoto Y, Yoshioka M, Kagi N, Hasegawa K, Yoshino H and Yanagi U (2014), Indoor air quality and thermal comfort in temporary houses occupied the Great East Japan Earthquake. Indoor Air, (24) : 425-437.

[7] Albadra D, Vellei M, Coley D and Hart J (2017), Thermal comfort in desert refugee camps: An interdisciplinary approach, Jordan. Building and Environment. (124) : 460477.

[8] Arslan H and Cosgun N (2008), Reuse and recycle potentials of the temporary house after occupancy: Example of Duzce, Turkey. Building and Environment, (43) : 702-709.

[9] Cassidy J (2007), Strategic planning for post-disaster temporary housing. Article in Disasters, 31 (4) : 435-458.

[10] Ying Y, Enshen L, Yuan S and Hongxing Y (2016), Assessing the thermal performance of temporary shelters. Procedia Engineering, (159) : 174-178. 
[11] Salvalai G, Imperadori M, Scaccabarozzi D and Pusceddu C (2015), Thermal performance measurement and application of a multilayer insulator for emergency architecture. Applied Thermal Engineering, (82) : 110-119.

[12] Obyn S, Van Moeseke G and Virgo V (2015), Thermal performance of shelter modelling: Improvement of temporary structures. Energy Building, (89) : 170-182.

[13] Thapa R and Rijal HB (2016), Study on thermal environment and thermal comfort in autumn season of temporary shelters in Nepal after massive earthquake 2015. Lowland Technology International, 18 (2) : 119-128.

[14] Thapa R, Rijal HB and Shukuya M (2018), Field study on acceptable indoor temperature in temporary shelters built in Nepal after massive earthquake 2015. Building and Environment, (135) : 330-343.

[15] H.M.G, of Nepal. Climatological records of Nepal: Ministry of science and technology (1991-1994). Department of Hydrology and Meteorology, Kathmandu.

[16] Meteorological observatory, H.M.G, of Nepal. Climatological records of Nepal, Ministry of science and technology (2015). Department of Hydrology and Meteorology, Kathmandu.

[17] Thapa R, Rijal HB and Shukuya M (2017), Comparison of Wintery Indoor Air Temperature in Temporary Shelters in Nepal after Massive Earthquake 2015. AIJ Summaries of Technical Papers of Annual Meeting, Hiroshima, 515 -516.

[18] Thapa R, Rijal HB and Shukuya M (2018), Evaluation of Seasonal Thermal Environment of Temporary Shelters Built in Nepal after Massive Earthquake 2015. The 10th Windsor Conference: Rethinking Comfort, Cumberland Lodge, Windsor, United, 1202-1209.

[19] Rijal HB, Yoshida H and Umemiya N (2010), Seasonal and regional differences in neutral temperatures in Nepalese traditional vernacular houses. Building and Environment, 45 (12) : 2743-2753.

[20] Amatya M, Gorkhali B, Islam MN and Shrestha S (2014), Body mass index correlates with age but not with sleep duration in Nepalese adults. Journal of universal college of medical science, $(02):$ 15-18.

[21] Bajracharya SB (2013), The thermal performance of traditional residential buildings in Kathmandu valley. Journal of the institute of engineering, (10) 172-183.

[22] Sagiroglu M and Memari A (2018), Learning from the experiences of using different types of temporary housing systems. 42 IAHS world congress, The housing for the dignity of mankind, Italy.

[23] Salvalai G, Imperadori M, Lumina F, Mutti E and Polese I (2017), Architecture for refugees, resilience shelter project: A case study using recycled skis. Procedia Engineering, (180): 1110-1120. 